\title{
Design and Implementation of College Aerobics Network Course System in the Era of MOOC Network Teaching
}

\author{
Li Min \\ Jiangxi Science \& Technology Normal University, Nanchang, Jiangxi, 330013
}

Keywords: MOOC Lessons; Network Teaching; Aerobics in Colleges and Universities; Design and Implementation

\begin{abstract}
In the era of rapid development of educational undertakings, Mu lesson has become an important part of network teaching. The era of network teaching has entered the full time, and it has also been paid much attention by the education department and the society. The combination of Internet technology and education is becoming more and more closely. "MOOC lesson", as a new network course teaching system, should be born. In this paper, we use different analytical methods to explore the design and implementation of the online course selection system for aerobics in Colleges and universities, and draw a conclusion. MOOC can be used as an aerobics course platform for college students, innovative teaching methods and teaching classes to turn over. The training of students' ability is taken as the main point of attention, so as to promote the reform of teaching and sports, so as to improve the quality of aerobics teaching in China as a whole.
\end{abstract}

\section{Introduction}

The only way for today's educational system to develop in the long run is reform. It is the combination of network information technology and traditional education to promote the steady development of education. Before that, the education department issued some related educational improvement policies and measures, including the integration of information technology and education, and opening up a new chapter in the construction of education. At the same time, it is also mentioned that the training of talents, the construction of information resources and the education infrastructure should be put on the agenda [1-2]. MOOC is the product of adapting to the times, and constantly improving its online curriculum system in the process of development, which provides a precondition and foundation for the development of aerobics online course in Chinese universities.

\section{The MOOC Network Teaching}

\subsection{The characteristics of the MOOC network teaching}

First of all, mousse is the product of the birth of the idea of overturning the classroom. Compared with the passive learning mode in traditional classroom, MOOC transforms students from passive roles to active roles, while teachers transform curriculum guides from original classroom leaders. Secondly, the audience of the curriculum of the class has a trend of scale expansion. In MOOC online teaching, learning is not limited by time and place constraints, but rather through network clients [3]. Then, the web-based course has personalized learning way. Students can learn autonomously based on their own needs, formulate personal learning plans, understanding related learning progress and work hard to achieve free and enjoyable learning. Finally, the network course is the mode of community-based communication. In the course of the course, the students can discuss the problem with the teachers or the students to solve the problems in the course, whether it is on the line. In this process, we can not only promote communication and communication between teachers and students, but also play a role in improving students' self-learning ability, control ability, presentation ability, thinking ability and cooperation ability [4]. 


\subsection{The features of the content of the network course}

There are three modules in the content of the web-based curriculum and the first is the fragmentation of the content. MOOC in the network course is not in the traditional sense from easy to difficult to complex learning knowledge process is simple, but the unit classification knowledge and learning section. The learners' learning is chosen according to their own needs. The second block is the content of rich media, curriculum resources library Mu class compared to the traditional way of teaching is very large, which is rich in the reference documents, books, documents, materials, animation, video and other WPS courses with complicated teaching resources. The last one is the management process of the content, and the learning of the web-based curriculum is an incremental and rising self-management process [5]. The learning content has the corresponding task to complete, the unfinished knowledge point will be reminded, and can not carry on the next step of study. This makes the learning rules become very scientific, not caused by missing phenomenon in learning. The learning data can be recorded in detail, and the behavior of learning can be effectively managed.

\section{The Significance of the Aerobics Course in Colleges and Universities in the Era of MOOC Network Teaching}

\subsection{The abundance of aerobics resources in the MOOC class}

Students can share and exchange knowledge about aerobics courses, so that students can learn enough resources outside traditional classroom teaching. It is not only conducive to the cultivation of students' creative self-learning ability, but also overcome the shortage of resources in the traditional teaching model. At the same time, with the help of the network platform, the students' aerobics courses are extended beyond the classroom. The students' learning time and learning content have broken through the traditional restrictions, become efficient, and provide the students with rich related aerobics learning resources.

\subsection{Enriching the teaching means of MOOC aerobics}

MOOC platform can not only provide users with regular documents, formal documents, concise lesson plans, dynamic pictures, videos, but also provide interactive games. Therefore, MOOC class respects the autonomy and freedom of students to the greatest extent. The central idea of the class teaching is to transform the students from the traditional passive aerobics learning body into the active aerobics learning body [6-7]. The transformation of teachers from the main aerobics instructors to assisting the instructors of aerobics is conducive to the equal communication between teachers and students in aerobics learning. Improve the students' overall aerobics learning level by answering questions online, discussing questions and arranging homework.

\subsection{The innovation of MOOC aerobics teaching mode and method}

In the process of aerobics teaching in the MOOC network course, the teaching mode of teachers' guidance and students' autonomy are fully displayed. It has created an active and open learning atmosphere, created a relaxed and vivid teaching environment, and realized a diversified style of teaching. By combining the advantages of online teaching and offline teaching, the multiparty mutual learning activities between students and students are facilitated. It not only improves the enthusiasm and interest of the students' aerobics, but also gives play to the greatest possibility of students' creative learning to a certain extent. In order to improve the students' innovative aerobics learning ability, the methods and methods of the students' aerobics to participate in the study are guided [8].

\subsection{Promoting the reform of the syllabus of aerobics teaching materials and the improvement of the quality of the personnel}

The reform of the aerobics online course syllabus and teaching material under the MOOC platform of curtain plays a positive role in the construction and development of the aerobics course, 
and follows the principle of practical life-long. Based on the actual resources of colleges and universities and the reality of students, we should carry out the innovation of textbooks, achieve the integration of entertainment and fitness, and update and use all practical new textbooks.

In the development of the MOOC web-based curriculum, there is a new requirement for the teachers' own knowledge and literacy. The aerobics teachers must have the teaching values of advancing with the times and innovating and developing. Adhering to the advanced educational thoughts, we can contribute to the development of the MOOC aerobics course [9-10]. The construction and enhancement of teaching staff and the adjustment and improvement of teachers' structure can be realized by the way of independent learning and studying abroad, combined with the updating of modern teaching methods. It is the requirement of modern education to build a new era of aerobics MOOC teachers with high quality, good quality and good work.

\section{Design and Implementation of Aerobics Network Course System in the Era of MOOC Lesson}

\subsection{Design of aerobics network course in MOOC lesson University}

Teachers play a good role in their role is the key to the MOOC lesson and the focus of the curriculum is the design of the lesson. The design of the MOOC class aerobics course mainly includes: curriculum preparation, curriculum design, curriculum content, curriculum organization, curriculum management, statistical analysis, curriculum, curriculum effect feedback again using these pieces, but also follow the rules are: with knowledge as the guide to the curriculum design, teaching design of importance path the teaching effect and to highlight education and goal, fun of teaching philosophy.

The construction of aerobics MOOC curriculum is mainly composed of the following processes: teaching material selection, teaching curriculum planning, curriculum knowledge design, teaching curriculum design, teaching course production, teaching course post production, propaganda and shooting teaching practice [11-12]. In the process of teaching, teachers first set contents according to the outline, and then made teaching plans according to contents, and finally emphasized the key points in teaching, so that students could clearly understand the difficulties of action. Following the post - production of teaching video, it was submitted and uploaded to the students for study.

\subsection{The realization of aerobics network course in MOOC university}

Aerobics MOOC curriculum teachers can send out teaching materials to students at any time and place for study, and at the same time we can see students' learning progress and supervise and understand students' learning. At the same time we can also set up the homework for the students to review and consolidate after class, online correcting homework also reduces the volume of the teacher's work. Compared with the traditional teaching mode, MOOC teaching system is more perfect, more attention is paid to students' learning process, and students' learning methods are also varied. Computer and mobile terminals can achieve aerobics curriculum learning. The combination of online learning and online learning, using the advantage of flipping the classroom, reflected in the following aspects: first of all the students can review the self-selection of knowledge point data in a certain period of free learning efficiency, the students' learning situation to have high clear understanding and understanding among the students and the level of their own ranking. Finally, the data traffic in the background facilitates teachers to grasp the dynamics of students in time and accurately, and achieve learning density and efficiency based on students' staged tasks.

\section{Conclusion}

In the era of MOOC network teaching, the teaching method of the course is playing an important role in the development and reform of aerobics teaching. To a certain extent, it can complement the traditional aerobics teaching deficiencies, aerobics teaching to the scientific system, diversification and rich taste development, realize the aerobics course "class integration" model built and flipped classroom implementation. It not only satisfies students' need for aerobics innovation, but also 
improves the teaching quality of aerobics course. It is the direction of reform and development of College Physical Education in the future.

\section{References}

[1] Zhang L H, Li F. Application of the SPOC Teaching Mode in Courses of Computer Network in the Post-MOOC Period[C]// International Conference on Information Technology in Medicine and Education. IEEE, 2017.

[2] Fang B, Yang C, Chen R, et al. Study on the New Teaching Model of Universities' Liberal Arts Curriculum Education in the "Post- MOOC” Era[J]. Modern Distance Education, 2015.

[3] Wang S, Zhou Q, Education S O, et al. Dissimilation and Reconstruction of Relations between College Students and Teachers in the Era of MOOC[J]. Education \& Teaching Research, 2017.

[4] Li H, University S. The Application of "Mooc" in The Instruction of Modern Chinese[J]. Journal of Qilu Normal University, 2016.

[5] Liu Q. The Teaching Model Reform of the Local Colleges and Universities under the Background of MOOC Era[C]// International Conference on Education, Management and Computing Technology. 2015.

[6] Mao P. Research on Teaching Reform of Management Information System in MOOC Era[J]. Modern Computer, 2016.

[7] Gui-Zhen L I, Department F L, University H. On New Forms of College English Teaching and Teachers' Development Strategies in MOOC Era[J]. Journal of Heze University, 2016.

[8] Chen Q, Fang B. Understanding and Application of Network Interaction_—Discussion on the Course Design of College Literature[J]. Education Teaching Forum, 2017.

[9] Li-Chuan X U, Shen S J, Liu Y. Application of MOOC in Teaching Design of Practical Courses in Colleges and Universities[J]. Research \& Exploration in Laboratory, 2016.

[10] Cao J F, Wang H B. Discussion on the teaching mode reconciling MOOC of network engineering specialty in local universities and colleges[J]. Journal of Science of Teachers College \& University, 2016.

[11] Liu Q. The Teaching Model Reform of the Local Colleges and Universities under the Background of MOOC Era[J]. 2015.

[12] Cai J, Guo D, University H E. Exploration of network finance course teaching in Big data environment[J]. Computer Era, 2015. 